\title{
On Cultural Factors in Sino-American Business Negotiations
}

\author{
Liguo Shi \\ School of Foreign Language \\ Wuchang Institute of Technology \\ Wuhan Hubei, China
}

\author{
Xiaojuan Zeng \\ School of Foreign Language \\ Wuchang Institute of Technology \\ Wuhan Hubei, China
}

\begin{abstract}
Business negotiation plays a significant role in the business activities. But the daily increasing issues reflect that there are so many problems in international business negotiations caused by cross-cultural differences. As the ways of thinking and behavior differ a lot between Chinese and American, and if negotiators are not familiar with their partners' culture, the cross-cultural negotiation habits and related knowledge, there will definitely be some obstacles in understanding which easily leads to mistakes in their communication, and even some serious mistakes that could ruin their business. So this paper first explores the cultural factors in international business negotiation, and then puts forward some strategies to deal with the cultural problems.
\end{abstract}

Keywords-cultural; difference; international; business negotiation; strategies

\section{INTRODUCTION}

\section{A. Research Background}

With the developing of economy and the arrival of global information age, the smaller and smaller the world becomes the closer and closer the international connections turn to be. The most popular part of those connections definitely is business communications. Meanwhile, organizations and individuals from different countries or regions sprout out a strong need and desire to connect with each other, especially the trade between Chinese and America. In recent years, Chinese economy develops rapidly after them carrying out the reform and opening-up policy as well as making all their efforts to their modernization construction. Chinese people are willing to step out and learn new knowledge. At the same time, a lot of foreign businessmen are attracted to China by its large market and potential business opportunities. As one of them, America is a typical developed country with the national spirit of courage, exploration, competition and freedom. Developing economy well is also their most important matter on agenda. Both China and America catch the chance to push their economy forward. In order to get an agreement, all of their business activities cannot proceed without the business communication which is usually called business negotiation. Business negotiations are just a special model of the crosscultural communication, which are ruled by the common cross-cultural communication regulation as well as its own features. China is the biggest developing country with a long history and complicated cultural system, and she is the representative of eastern cultures. While, American is the biggest developed capitalist and country, and acts as the representative of western cultures. Obviously, the two kinds of cultures vary dramatically on their way of thinking and behavior. So, it is very important to understand the cultural difference and adopt efficient strategies accordingly.

\section{B. Purpose and Importance of Research}

Business negotiation has already been a common phenomenon in business trade. Only when the two parties have the same interest will they have the desire to cooperate with each other. Due to the difference in social and economic situation, there are so many conflicts in Sino-American trade. The difference, which regularly is called the cross-cultural difference, means that negotiators' language, behavior, time concept, communication skills, and the way of thinking are different in a large extent. Intercultural differences make the negotiation process complicated and diversified [1]. Understanding the language and behavior of negotiators is the basis of a successful communication which can obtain a mutually beneficial agreement. The problem of intercultural communication tells us that there is a need for us to research the cross-cultural elements during the process. Through researching the strategies, methods, skills, tactics, measures used by negotiators in the process of business communication for a targeted goal, the paper wants to find some acceptable methods for two parties (China and America) to communicate with each other. What's more, a good acquirement of crosscultural knowledge will be useful to avoid the cultural conflict, strengthening the harmonious in international talk, and improving the successful rate of international business negotiation.

\section{Cultures And Business Negotiation}

\section{A. What Is Culture?}

Scholars from different cultures give different definition about culture. According to A New Concise Course on Linguistics for Students of English by Dai Weidong published by Shanghai Foreign Language Education Press, culture, in a broad sense, means a total way of a people, including the ideology, patterns of belief, customs, objects, institutions [2]. Techniques and languages that characterize the life exist in the 
human community. Culture is characterized by groups. Culture includes both elements, namely which are shared values and norms by members of the group, and social structure elements. Besides, the social interaction background of economic, social, and religious system is reflected through culture. Culture is conscious about social relations, including values, social thought and morality. Social-economic and political practice are the foundation and carrier of culture. As culture is so inclusive, it permeates virtually every aspect of human life and influences predominantly people's behavior.

In a marrow sense, culture may indicate local or specific practice, beliefs, custom, which can be mostly discovered in folk culture, enterprise culture or food culture. It is a system of shared beliefs, values customs, behaviors and artifacts that the member of a community use to react with the world and with the another and that are transmitted from generation to generation [3]. Generally speaking, there are two types of culture: material culture and spiritual culture. Culture covers aspects of our daily life.

Chinese scholars generally believe that culture is a sum of social customs supporter and norms in specific group of people, also as a link connecting social people during a longterm environment in social life [4].

\section{B. What Is Business Negotiation?}

Negotiation is a dialogue between two or more individuals or parties, intended to reach an understanding, resolve point of difference, or gain advantage in outcome of dialogue; to produce an agreement upon courses of action, to bargain for individual or collective advantage, to craft outcomes to satisfy various interests of two individuals or parties involved in negotiation process. Negotiation is a process where each party involved in negotiating tries to gain an advantage for themselves by the end of the process. Negotiation is aimed at compromise. Negotiations usually occurs in the following occasions, such as, business, non-profit organizations, government branches, legal proceedings, among nations and in personal situations [5].

Business negotiation occurs in business, and usually most are profitable activities. Business negotiation means the behavior and processes, in which the parties from different countries and regions in business activities, in order to meet their own needs, communicate and exchange of information to reach consensus [6]. The bodies of negotiating belong to two or more countries or regions, and the negotiators represent different interests of their own party. Meanwhile, negotiation is influenced by cross-cultural elements. Negotiators from different background have different social values, ways of thinking or behavior, communication patterns, language and customs. These cultural factors will have a direct impact on the result of international business negotiations [7]. In this sense, international business negotiations should be named crosscultural business negotiations, the failure of such negotiations rarely due to technical or professional reasons but crosscultural differences occurred in the negotiation process. With different ethnic and cultural heritage, knowledge, experiences and the way of thinking, eastern and western countries often have conflicts in understanding.
During the negotiation, each party wants to persuade the other to agree with his or her point of view. For example, negotiators bargain to reduce debts, to cut down the sale price of a car, to get a better deal on a real estate or to improve the conditions of a contract.

\section{CROSS-CUltural DIFFERENCES IN BUSINESS NEGOTIATIONS}

As an important part of business activities and a kind of cross-border activity, international business negotiation is that negotiating parties conduct consultations on issues of common interest and the commercial consensus. With the development of globalization, international business negotiation has become a common phenomenon in current business activities. International business negotiation is affected by many factors in their respective countries, the nation's politics, economy, culture and others. Negotiators from different cultural backgrounds have different ways of communication, values and ways of thinking, which means that understanding of the different cultures in international business negotiations and the familiarity with business activity, are very important to deal with cultural differences. Cultural differences in international business negotiations lead to a culture clash or conflicts, As a result, considerable negotiations failed, which directly affect the smooth conduct of international business activities. Therefore, in international business negotiations, cultural factors are critical to correctly grasp.

\section{A. Language Difference}

In international business negotiations, when there is a huge difference in meaning but with similar expressions in two different languages, as well as some kind of expression only existing in one language, which can easily cause confusion in communication. For example, in China, one of the ways that government manages business is to assess the situation or rank of enterprises based on the level of business management and enterprise scale, such as "National Enterprise", "The Provincial Enterprise," and so on. While in America concept, they do not have a clear idea about the nature. They regard "National Enterprise", "The Provincial Enterprise" as "First Class Enterprise" and "Second Class Enterprise", difficult for the other side to understand the meaning of this expression, and the negotiations would not achieve the same effect as in the domestic expression, moreover there are likely to misunderstand each other, such as the "First Class Enterprise" and "Second Class Enterprise".

Even countries with the same language still have some differences in some expression, such as English-speaking countries (America and the United Kingdom). For example, "first floor" in the English refers to the second floor, while American English refers to the first floor, and English tends to use "ground floor" to mean the first floor. "Corn" in English refers to the grains, wheat, equivalent to American English "wheat", and American English "corn" is equal to the English "maize".

In formulating bargaining agreements, the issue of language differences deserves deep analysis and research. 


\section{B. Behavior of Language Differences}

Cultural differences in behavior are often too subtle to be realized. When foreign negotiators make different non-verbal signals, the negotiator with different cultural backgrounds can easily misunderstand these signals, and be unaware of error which is conveyed. People in some countries or regions would like to use oral expression along with a lot of action language, while some people from another country or region are not accustomed to the use of the magnitude of the action language in formal occasions. The understanding and use of the behavior of language difference will also bring problems to communication and negotiation.

For example, the communication style of Chinese businessman is the most polite, more use of positive commitment, recommendations and assurance, less use of threats, commands and warnings remarks. However, America businessman negotiating style is more presumptuous, and they use a higher frequency of threats and warnings language, very frequently interrupted with solemn facial expression.

\section{Differences in Communication.}

People from different background have their own preferences and habits of communication. The two parties in international business negotiations often belong to different cultural the same to their customary way of communication. The two sides that are accustomed to using different communicating styles which tend to produce a variety of problems. For example, in China and Japan, people are usually more tactful and indirect expression. But in the United States or Germany, straightforward expression is more common. Chinese, Japanese negotiators pay more attention to the discovery and understanding of underlining expression without being expressed orally, but negotiators of United States, Germany, prefer for greater use of verbal, direct or easily received clear message. When negotiators from the two different cultures during the negotiations, one party may be thought too reckless, however the other may look like lacking sincerity in negotiations, or misunderstanding the silence of the other side as an endorsement of the proposed conditions.

\section{Differences in Ways of Thinking}

In international business negotiations, negotiators from different cultures often encounter conflicts on the way of thinking. For example, in eastern culture and Anglo-American culture, the difference in ways of thinking is: Oriental cultural prefers to visual thinking, while Anglo-American cultural prefer to abstract thinking. Oriental cultural prefer to comprehensive thinking, while Anglo-American cultural prefer to analytic thinking. Asians focus on unity, while the Anglo-American pays attention to the position. Besides, Chinese philosophy, though not denying the opposition, pays more emphasis on harmonization, while westerners put everything into two opposing ways

The international economic communication usually means that negotiators from different cultures with a common purpose get together in a social environment where negotiators are unfamiliar with the other's cultural characteristics. In the communication taken by the parties from different cultures and different societies that have experienced the different process of economic affairs, negotiators will easily conduct overlapping phenomenon. Exchanges and communication in this cultural overlapping context are constrained by the words and deeds of both the unique cultural patterns of behavior.

\section{STRATEGIES To DEAL WITH INTERCULTURAL DiFFERENCES}

\section{A. Greeting}

Greeting is to learn about the client's background and interests, thereby selecting important clues in order to obtain an appropriate follow-up communication method. For example, they can begin the talk by sharing the weather or travel experiences.

\section{B. Persuading--Deal with Disagreement}

The persuading skill is an important kind of art. The understanding to persuasion and the way to persuade others are various from different people. In focusing on the relationship between the vertical position of the culture, people often tend to pay more time and effort on work-related information exchange or pleasantries, but very little "debate" on stage of convincing content. Even use of persuasion, people usually takes indirect way and vivid words due to avoiding the feeling of sudden or awkward. Moreover, the method and results of persuasion will be also related with the status of the relationship. For example, in China, if the way of communicating is too direct, people will think that you do not consider their personal feelings.

\section{Coming to an Agreement}

Due to differences of thinking modes, negotiation of different cultures shows differences in decision-making, and there will be some conflicts through negotiations between the decision-making methods. When facing a complex negotiation task, sequential decision-making method is usually used in Western culture, especially in American people who often divide big task into a series of smaller tasks. The price, delivery, warranty and service contracts to solve the problem are arranged in several different time to settle, and when each problem is settled down, there are concessions and commitments from beginning to end, a series of small agreements form the final agreement. However, the oriental culture commitment to reach a package agreement usually uses the overall decision-making methods, and not until the final step of negotiation will they make concessions on all issues.

\section{Making Fully Preparations}

Before international business negotiations, negotiators should be familiar with the opponent negotiator's cultural norms, customs, social values, national current situation. Only in this way can they avoid causing unpleasant or misunderstanding, which affects the progress and results of the negotiations, and they can not only know the literal meaning but a deep understanding. Success always favors those who are prepared, if not some necessary preparations, it means preparing to fail. For example, through a long-term market research a British businessman finally found an ideal Chinese 
enterprise. In order to establish better business relationships with this business, he decided to visit this enterprise, and he knew it was better to bring a gift. He wanted to buy a bottle of wine, but was afraid that Chinese people might think that he is the excessive drinker, while he wanted to buy a high-tech product, but afraid of not enough sense of personal emotion. Later, he suddenly got an idea that local restaurants in Guangzhou worship Buddha everywhere, so he thought the Chinese people probably had such faith, and he finally brought a pack of joss candles to Chinese partners. Of course, he lost the deal, because he didn't make fully preparation.

\section{E. Overcoming Customer's Communication Barriers}

Language is an important communication tool between countries, but also tools for cross-cultural communication. Sometimes, if they cannot understand other's language well, there is no way to have further cross-cultural exchange. In international negotiations, negotiators usually communicate in English. They should try to use simple, clear, clear English, instead of any misunderstanding of politely, puns, slang, idioms, or some offensive words. To interpret or judge the behavior of some other groups in one's own opinion can easily lead to cultural bias and cultural conflict. In international business negotiations, negotiators need to eliminate prejudice which is conducive to the smooth progress of the negotiations. When contacting with foreign opponents, some of their habits in the other party's opinion are very rigid and even funny. However, they have to respect each other's habits.

\section{F. Building the Cross-cultural Awareness}

The so-called cross-cultural communication refers to the participants not only rely on your own code, habits, attitudes and behavior, but also experience and understand each other's all relationships between code, habits, attitudes and behavior. The latter is considered to be a strange and novel. Therefore, cross-cultural relations, including sexual behavior center, all the features and strange new self-heterosexual identity, peculiar sense of intimacy easygoing or dangerous, normal things and new things together participants, ideas, feelings and understanding, play a comprehensive role. In international business negotiations, there is a need to strengthen crosscultural awareness and understanding of the needs, motivations and beliefs of the negotiators from different cultures backgrounds, and learn to understand, accept and respect each other's culture. Of course, recognize that cultural differences do not completely mean that the customer will be able to easily handle their influence, but at least will be provided an opportunity to overcome obstacles caused by ignorance of cultural difference. Under the guidance of the correct sense of the negotiations, international negotiators are more flexible and changeable, so that their negotiating styles and strategies can be easily adapted to the business influenced by different culture.

\section{CONCLUSION}

Sino-American business negotiations and culture are inseparable. Negotiation is a complicated social process, which requires high-quality communication to solve the problems aroused from cultural differences in negotiations. To be a successful cross-cultural business negotiator, many factors should be taken inter consideration. First the two parties must learn to observe the opponent's culture, compare it with their own culture, try to understand and respect different cultures and traditional customs. The two parties should create a friendly atmosphere, which will affect the interpersonal relationship, especially "the trust" between each other. What's more, good cross-cultural communication is a guarantee to achieve a win-win economic effect. Fully preparing, skillful using cultural negotiation skills, and then the chances of success of the negotiations between the two countries will be greatly increased. As two big countries, the successful business negotiation between China and America will prove their friendly relationship, and set an example for other countries.

\section{REFERENCES}

[1] Li Sha, Sun Ting, "Research on Business Negotiation from the Crosscultural Communication Perspective" in Literature Education , 2011, pp. 54-55.

[2] Dai Weidong, Liu Runqing, A New Concise Course on Linguistics for Students of English, Shanghai: Shanghai Foreign Language Education Press, 2006, pp. 76-79.

[3] Hofstede, Geert, Culture's Consequences: International Differences in Work-related Values, Deverly Hills CA: Sage Publication, 1980.

[4] Sang Lamei, "International Business Negotiation Strategy Based on Cross-cultural Communication" in Crazy English Teachers, 2011, pp. 162-164.

[5] Negotiation, http://en.wikipedia.org/wiki/Negotiation. July $3^{\text {rd }}, 2015$.

[6] Faure, G. O., "Negotiation: The Chinese Concept" in Negotiation Journal, 1998, pp. 137-148.

[7] Faure, G. O., "Negotiations to set up joint ventures in China" in International Negotiation, 2000, pp.157-189. 